GU J Sci, Part C, 6(4): 765-773 (2018)

Gazi Üniversitesi
Fen Bilimleri Dergisi
PART C: TASARIM VE TEKNOLOJI
http://dergipark.gov.tr/gujsc

\title{
Sertleştirilmiş X40CrMoV5-1 Çeliğinin Tornalanmasında Kesme Kuvvetinin Deneysel ve Nümerik Olarak İncelenmesi
}

\author{
Nafiz YAŞAR ${ }^{1, *}$, Hakan YURTKURAN ${ }^{2}$, Mustafa GÜNAY3 \\ ${ }^{1}$ Karabük Üniversitesi, Yenice Meslek Yüksekokulu, Raylı Sistemler Makine Teknolojisi Bölümü, 78080, Yenice/KARABÜK \\ ${ }^{2}$ Bozok Üniversitesi, Akmağdeni Meslek Yüksekokulu, Makine Bölümü, 66300, Akmăgdeni/YOZGAT \\ ${ }^{3}$ Karabük Üniversitesi, Mühendislik Fakültesi, Makine Mühendisliği Bölümü, 78080, KARAB̈̈K
}

Makale Bilgisi

Başvuru: 29/01/2018

Düzeltme: 13/07/2018

Kabul: 07/08/2018

\section{Anahtar Kelimeler}

Sert tornalama

Deform $3 D$

Takım çeliği

Keywords

Hard turning

Deform $3 D$

Tool steel
$\ddot{O} \mathbf{z}$

X40CrMoV5-1 sıcak iş takım çeliği, enjeksiyon ve ekstrüzyon kalıplarında yüksek sıcaklık, tokluk ve aşınma direnci gerektiren parçaların imalatında yaygın olarak kullanılır. Diğer yandan, silindirik parçaların nihai geometriye getirilmesinde, taşlama yerine sert tornalamanın tercih edilmesi üretim zamanı ve maliyeti azaltırken, aynı zamanda parçanın yorulma mukavemetinde iyileşme sağlamaktadır. Bu çalışmada, vakumla 1sıl işlemde $55 \pm 1$ HRC'ye sertleştirilmiş X40CrMoV5-1 takım çeliğinin seramik kesici takımlar (kaplamalı ve kaplamasız) kullanılarak tornalanmasında elde edilen esas kesme kuvveti $(\mathrm{Fc})$ değerleri deneysel ve nümerik olarak incelenmiştir. Sert tornalama deneyleri, kesme parametrelerinin (ilerleme hızı, kesme hızı ve kesme derinliği) farklı seviyeleri kullanılarak Taguchi L32 deney tasarımına göre gerçekleştirilmiştir. Fc değerlerinin deneysel olarak belirlenmesinde Kistler 9257B dinamometre ve ekipmanları kullanılmıştır. Sonlu elemanlar yöntemine dayalı olarak yapılan kesme simülasyonları DEFORM 3D yazılımında gerçekleştirilmiştir. Ayrıca, kesme parametrelerinin Fc üzerindeki etkileri güven düzeyi $\% 95$ olan varyans analizi (ANOVA) ile belirlenmiştir. Fc değerleri için deneysel ve nümerik analiz sonuçları arasındaki benzerlik kaplamasız takımlar için ortalama \%94, kaplamalı takımlar için \%91 olarak bulunmuştur. Deneysel verilere dayanılarak yapılan ANOVA sonuçlarına göre en önemli faktörün kesme derinliği olduğu tespit edilmiştir.

\section{Experimental and Numerical Investigation of Cutting Force in Turning of Hardened X40CrMoV5-1 Steel}

\begin{abstract}
$\mathrm{X} 40 \mathrm{CrMoV} 5-1$ hot work tool steel is commonly used in injection and extrusion molds and also manufacturing of parts requiring high temperature, toughness and abrasion resistance. On the other hand, the preference of hard turning instead of grinding reduces the production time and cost, while improving the fatigue strength of the part in the case of putting the cylindrical parts into final form. In this study, the main cutting force $(\mathrm{Fc})$ was investigated experimentally and numerically during machining of hardened X40CrMoV5-1 tool steel with vacuum and heat treatment to $55 \pm 1$ HRC by coated and uncoated ceramic inserts. Hard turning experiments were performed according to the Taguchi L32 experimental design using different levels of cutting parameters (feed rate, cutting speed and depth of cut). Kistler 9257B dynamometer and equipments were used in experimentally determination of Fc values. Cutting simulations based on the finite element method were performed in DEFORM 3D software. In addition, the effects of cutting parameter on Fc were identified via analysis of variance (ANOVA) at 95\% assurance level. The similarity between experimental and numerical analysis results for Fc values was found to be $94 \%$ for uncoated tools and $91 \%$ for coated tools. It was determined that depth of cut is the most important factor according to ANOVA results obtained by using experimental data.
\end{abstract}

\section{GİRIŞ (INTRODUCTION)}

Taşlama operasyonları daha iyi yüzey kalitesi ve ölçü tamlığı istenilen yerlerde yaygın olarak kullanılmaktadır. İşleme süresinin fazla olması ve buna bağlı olarak işleme maliyetlerinin artmasıyla taşlama operasyonlarının yerini sert tornalama işlemleri almaktadır. Bunun yanı sıra kuru sert işleme operasyonlarının esneklik ve pozitif ekolojik etkileri diğer avantajları olarak bilinmektedir [1]. Ayrıca, sert 
tornalama sonucu elde edilen parçalar taşlama operasyonu ile kıyaslandığında daha uzun yorulma ömrüne sahip olduğunu söylemek mümkündür [2].

Son zamanlarda, yüksek ölçü tamlığı, düşük takım maliyeti, daha az işlem süresi ve kesme sıvısı kullanımına gerek olmaması gibi avantajlarından dolayı sertleştirilmiş çeliklerin işlenmesi endüstriyel imalat ve bilimsel araştırmaların ilgi odağı haline gelmiştir. Sert tornalama operasyonunun karmaşık parçaların üretimi için kullanılması üretim maliyetinin \%30 oranında azaltacağı öngörülmektedir [3]. Ayrıca, sert tornalama işleminin ana amacı takım maliyetine ve kesme şartlarının işlenebilirlik özelliklerine pozitif olarak katkı sağlamasıdır. Sertleştirilmiş çeliklerin işlenmesinde CBN (kübik bor nitrür), PCBN (polikristal kübik bor nitrür) ve seramik kesici takımların kullanılması, işleme zamanını azaltmak ve yağlamayı önlemek için taşlama operasyonunun yerini aldığı bilinmektedir [4]. Bu bağlamda, Aouici ve arkadaşları [5] seri üretimde maliyet ve işleme zamanını azaltmak için kesme koşullarının optimizasyonundan söz etmişlerdir. Tepki yüzey metodu (RSM) kullanarak CBN kesici takımla AISI H11 takım çeliğinin sert tornalanmasında bir optimizasyon çalışması gerçekleştirmişlerdir. Sonuç olarak kesme kuvveti bileşenlerinin kesme derinliği ve iş parçası sertliğinden etkilendiğini belirtmişlerdir. Bouacha ve arkadaşları [6] sert tornalamada farklı iş parçası sertliği ve kesme hızının, takım aşınması ve kesme kuvveti üzerindeki değişimlerine odaklanmışlardır. Ayrıca, kesme parametrelerinin kesme kuvvetleri üzerindeki etkisini incelemişlerdir. İlerleme kuvvetinin en yüksek kesme kuvveti bileşeni olduğunu ve iş parçası sertliği, negatif talaş açısı ve takım aşınmasının gelişimine oldukça duyarlı olduğunu gözlemlemişlerdir. Son olarak kesme derinliğinin kesme kuvveti üzerinde kesme hızı ve ilerleme miktarı ile kıyaslandığında en etkili parametre olduğunu tespit etmişlerdir. Oh çalışmasında [7], SKD 11 yüksek sertleştirilmiş çeliğinin CBN kesici uç ile sert tornalanmasında işleme özelliklerini belirlemek için kesme kuvvetini incelemiştir. Düşük kesme hızı ve yüksek ilerleme oranı ile işleme operasyonunun etkili olduğunu gözlemlemişlerdir. Ayrıca, ilerleme miktarının artmasına veya kesme hızının azalmasına bağlı olarak kesme kuvvetlerinin arttı̆̆ını belirtmişlerdir.

Deneysel işlemlerle gerçekleştirilen kesme işlemlerinde kesme kuvveti, sıcaklık, gerinim, gerinim hızı ve gerilme gibi işlenebilirlik özelliklerinin analizi için birçok zorluklar vardır. Bu yüzden, istenilen ölçü ve yüzey kalitesinden ödün vermeksizin üretim kapasitelerini arttırmak için işlenebilirlik özelliklerini tahmin eden sonlu elemanlar modelleri geliştirilmektedir. İşlenebilirlik özelliklerinin tahmininde, sonlu elemanlar yöntemi, regresyon analizi, yapay sinir ağı vb. tekniklerin kullanımı giderek artmaktadır. Sonlu elemanlar yöntemine (FEM) dayalı kesme simülasyonları uygulaması, işleme özelliklerini tahmin etmek için bu teknikler arasında en sık kullanılan yöntemdir. Birçok malzemenin işlenmesinde farklı kesici takım kalitelerinin performansı için birçok modelleme araştırması yapılmıştır. Vijayaraghavan ve arkadaşları [8] işlem değişkenleri ve kesme kuvveti arasındaki matematiksel ilişkiyi elde etmek için Genetik Programlama kullanmışlar ve kesme kuvvetinin tahmini için ise sonlu elemanlar modelini araştırmışlardır. Araştırmacılar elde ettikleri sonuçları deneysel veriler ile karşılaştırarak ABAQUS 3D ile uygulanan sonlu elemanlar modelinin geçerliliğini vurgulamışlardır. Yaşar ve arkadaşları [9] Karbür kesici takım kullanarak AISI P20 çeliğinin tornalanmasında meydana gelen kesme kuvvetinin $(\mathrm{Fc})$ deneysel ve nümerik analiz sonuçlarını incelemişlerdir. $\mathrm{Fc}$ değerlerinin deneysel ve nümerik analiz sonuçlarına göre, artan kesme derinliği ve ilerleme miktarlarında benzer eğilim göstererek artış sergilediği ancak artan kesme hızı ile azaldığını belirtmişlerdir. Deneysel olarak elde edilen Fc değerlerinin nümerik analize göre $\% 8$ daha düşük olduğunu, bu farkın AISI P20 malzemesinin malzeme modeline (Johnson-Cook) ve simülasyonlarda kullanılan kesici takım ve iş parçası arasındaki sürtünme katsayısından kaynaklandığını vurgulamışlardır. Gök çalışmasında [10], deneysel çalışmaların doğrulanması için yararlı olabilecek DEFORM 3D'yi kullanarak 3 boyutlu metal tornalama sürecini modellemiştir. Analitik ve deneysel olarak tespit edilmesi zor olan kesme kuvveti, takım aşınması, sıcaklık ve kayma açısı gibi parametrelerin bilgisayarda FEM'e dayalı olarak kolaylıkla tanımlanabileceğini, karşılaştırma yapıldığında deneysel ve FEM sonuçlarının makul olduğunu vurgulamıştır. Literatür araştırması sonucunda, tornalama üzerine birçok deneysel ve nümerik çalışma yapılmasına rağmen, sert tornalamanın FEM'e dayalı olarak yapılan çalışmaların çok az olduğu görülmektedir. Bu çalışmada, kaplamalı ve kaplamasız CBN kesici takım kullanılarak X40CrMoV5-1 takım çeliğinin ( $55 \pm 1 \mathrm{HRC}$ ) tornalanmasında elde edilen esas kesme kuvvetleri ile FEM'e dayalı yapılan nümerik analizler sonucunda bulunan kesme kuvvetleri karşılaştırılmıştır. Ayrıca, kuvveti üzerinde ilerleme, kesme derinliği ve kesme hızının etkileri deneysel ve istatistiksel yöntemler kullanılarak analizleri gerçekleştirilmiştir. 


\section{MALZEME VE YÖNTEM (MATERIAL AND METHOD)}

\subsection{Deneysel Çalışmalar}

$\mathrm{Bu}$ çalışmanın ilk aşamasında, kaplamasız CBN ve kaplamalı (TiAlN) kesici takım kullanarak X40CrMoV5-1 (DIN 1.2344) çeliğinin sert tornalanmasında kesme parametrelerinin kesme kuvveti üzerindeki etkileri araştırılmıştır. İş parçası olarak tokluğu yüksek, 1sıl şoklara dayanımlı, yüksek sıcaklıklarda aşınma dayanımını kaybetmeyen $0.4 \% \mathrm{C}, 1.0 \% \mathrm{Si}, 0.40 \% \mathrm{Mn}, 5.1 \% \mathrm{Cr}, 1.3 \% \mathrm{Mo}, 1.0 \% \mathrm{~V}$ kimyasal bileşimine sahip sıcak iş takım çeliği kullanılmıştır. Malzemeye vakumda sertleştirme yöntemi

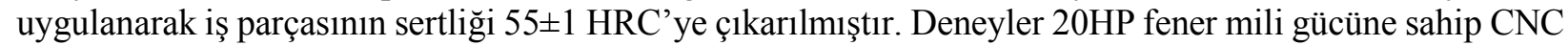
torna tezgahında gerçekleştirilmiştir. Tornalama deneylerinde kullanılan işleme parametreleri, kesici takım firma önerileri ve literatür incelemeleri sonucunda belirlenmiş olup, parametre seviyeleri Tablo 1'de verilmiştir. Taguchi L32 dikey dizininin tercih edildiği deney tasarımı ise Tablo 2'de verilmiştir.

Tablo 1. Faktör ve seviyeler

\begin{tabular}{|c|l|l|}
\hline Sembol & \multicolumn{1}{|c|}{ Faktörler } & \multicolumn{1}{c|}{ Seviye } \\
\hline $\mathrm{T}$ & Kesici takım & 1-Kaplaması, 2-Kaplamalı \\
\hline $\mathrm{V}$ & Kesme hızı (m/dak) & $150-200-250-300$ \\
\hline $\mathrm{f}$ & İlerleme miktarı (mm/dev) & $0,05-0,1-0,15-0,2$ \\
\hline $\mathrm{a}$ & Kesme derinliği (mm) & $0,1-0,2-0,3-0,4$ \\
\hline
\end{tabular}

Tablo 2. Taguchi L32 deney tasarımı

\begin{tabular}{|c|c|c|c|c|c|c|c|c|c|}
\hline Deney No & $\mathrm{T}$ & $\mathrm{V}$ & $\mathrm{f}$ & $\mathrm{a}$ & Deney No & $\mathrm{T}$ & $\mathrm{V}$ & $\mathrm{f}$ & $\mathrm{a}$ \\
\hline 1 & 1 & 1 & 1 & 1 & 17 & 2 & 1 & 1 & 4 \\
\hline 2 & 1 & 1 & 2 & 2 & 18 & 2 & 1 & 2 & 3 \\
\hline 3 & 1 & 1 & 3 & 3 & 19 & 2 & 1 & 3 & 2 \\
\hline 4 & 1 & 1 & 4 & 4 & 20 & 2 & 1 & 4 & 1 \\
\hline 5 & 1 & 2 & 1 & 1 & 21 & 2 & 2 & 1 & 4 \\
\hline 6 & 1 & 2 & 2 & 2 & 22 & 2 & 2 & 2 & 3 \\
\hline 7 & 1 & 2 & 3 & 3 & 23 & 2 & 2 & 3 & 2 \\
\hline 8 & 1 & 2 & 4 & 4 & 24 & 2 & 2 & 4 & 1 \\
\hline 9 & 1 & 3 & 1 & 2 & 25 & 2 & 3 & 1 & 3 \\
\hline 10 & 1 & 3 & 2 & 1 & 26 & 2 & 3 & 2 & 4 \\
\hline 11 & 1 & 3 & 3 & 4 & 27 & 2 & 3 & 3 & 1 \\
\hline 12 & 1 & 3 & 4 & 3 & 28 & 2 & 3 & 4 & 2 \\
\hline 13 & 1 & 4 & 1 & 2 & 29 & 2 & 4 & 1 & 3 \\
\hline 14 & 1 & 4 & 2 & 1 & 30 & 2 & 4 & 2 & 4 \\
\hline 15 & 1 & 4 & 3 & 4 & 31 & 2 & 4 & 3 & 1 \\
\hline 16 & 1 & 4 & 4 & 3 & 32 & 2 & 4 & 4 & 2 \\
\hline
\end{tabular}

İşleme deneylerinde, DNGA150404S01225 kodlu kaplamasız takımlar ile DNGA150404S01225 kodlu kaplamalı kesici takımlar kullanılmıştır. Kesici takımların rijit bir şekilde bağlanması için DDJNR 2525M12 kodlu takım tutucu kullanılmıştır. Kesici takım ve tutucu KYOCERA firmasından temin edilmiştir. Kesici takım ve takım tutucu kombinasyonunda, talaş açısı $(\gamma)$, boşluk açısı $(\alpha)$, eğim açısı $(\lambda)$ 
ve yaklaşma açısı $(\chi \mathrm{r})$ sırasıyla $-26^{\circ},-6^{\circ},-6^{\circ}, 93^{\circ}$ dir. Kesme kuvvetlerinin ölçümü, Multichannel Charge Amplifier (yükselteç) Kistler 5070A şarj amplifikatörüne bağlanan 9257B tipi Kistler piezoelektrik dinamometre ile gerçekleştirilmiştir. Verilerin bilgisayar ortamına alınmasında Kistler Dynoware yazılımı ve veri alma kartı (2855A3 A/D Board CIO-DAS 1602/12) kullanılmıştır. Tornalama sırasında harcanan enerjinin teorik olarak hesaplanmasında esas kesme kuvveti $(\mathrm{Fc})$ dikkate alınmaktadır. Bu bağlamda, deneyler sırasında ölçülen diğer ilerleme kuvveti (Ff) ve radyal kuvvet (Fr) bileşenleri değerlendirmeye alınmamıştır.

\subsection{Nümerik Analiz}

Sert tornalama operasyonunun sonlu elemanlar yöntemine dayalı olarak yapılan nümerik analizleri (kesme simülasyonları) DEFORM 3D yazılımı kullanılarak gerçekleștirilmiștir. Nümerik analizler öncesinde kesici takım katı modeli oluşturulmuş ve sonrasında kesici takım ile işparçası malzemesinin mekanik özellikleri tespit edilmiştir. Kesici takım üreticisi tarafından verilen değerler doğrultusunda SolidWorks programı kullanılarak kesici takım üç boyutlu modeli oluşturulmuştur. Simülasyonlar için Lagrangian Incremental mesh modeli kullanılarak iş parçası ve kesici takım 3D ağ yapısı oluşturulmuştur.

Simülasyonların gerçekleştirilmesi için DEFORM 3D programının Turning modülü seçilmiştir. X40CrMoV5-1 takım çeliğinin tornalanmasında, sürtünme faktörü, 1sı transferi katsayısı ve başlangıç sıcaklığı olarak sırasıyla $0.5,45 \mathrm{~N} / \mathrm{smm}^{\circ} \mathrm{C}$ ve $20^{\circ} \mathrm{C}$ kullanılmıştır. Kesici takımın kaplamasız özellikleri ve iş parçası malzemesi için mekanik ve fiziksel özellikler Tablo 3'te gösterilmiştir. Kesici takımın kaplamalı olduğu durumlarda kaplama malzemesi TiAlN seçilmiş ve kaplama kalınlığg $0,3 \mathrm{~mm}$ olarak alınmıştır.

Tablo 3. İş parçası ve kesici takım malzeme özellikleri [12-13]

\begin{tabular}{|l|l|l|}
\hline \multirow{2}{*}{ Yoğunluk $\left(\mathrm{Kg} / \mathrm{m}^{3}\right)$} & X40CrMoV5-1 & 7800 \\
\cline { 2 - 3 } & CBN (Kaplamasız) & 15000 \\
\hline \multirow{2}{*}{ Elastikiyet modülü $(\mathrm{GPa})$} & X40CrMoV5-1 & 211 \\
\cline { 2 - 3 } & CBN (Kaplamasız) & 720 \\
\hline \multirow{2}{*}{ Is1l genleşme $\left(10^{-6} /{ }^{\circ} \mathrm{C}\right)$} & X40CrMoV5-1 & 0,28 \\
\cline { 2 - 3 } & CBN (Kaplamasız) & 0,2 \\
\hline \multirow{2}{*}{ Iss1 iletkenlik } & X40CrMoV5-1 & $10,4 \mathrm{e}-06$ \\
\cline { 2 - 3 } & CBN (Kaplamasız) & $4,5 \mathrm{e}-06,25$ \\
\hline \multirow{2}{*}{ Özgül 1s1 $\left(\mathrm{J} / \mathrm{kg}^{\circ} \mathrm{K}\right)$} & X40CrMoV5-1 & 37 \\
\cline { 2 - 3 } & CBN (Kaplamasız) & 60 \\
\hline & X40CrMoV5-1 & 560 \\
\cline { 2 - 3 } & CBN (Kaplamasız) & 690 \\
\hline
\end{tabular}

Kesme simülasyonlarında, ağ yapısı (kesici takım ve iş parçası) modellenmiş olup, kesici takım üzerinde en küçük eleman boyutu deneme-yanılma yöntemi ile $0.1 \mathrm{~mm}$ belirlenmiştir. Öncesinde $1 \mathrm{~mm}, 0.5 \mathrm{~mm}$ ve $0.2 \mathrm{~mm}$ eleman boyutu kullanılmış fakat $0.2 \mathrm{~mm}$ 'den $0.1 \mathrm{~mm}$ 'ye geçişte kuvvet değerlerinde gözle görülür bir değişim görülmemiştir. Eleman boyutunun daha az olup, simülasyon süresinin daha fazla olmasına gerek duyulmamıştır ve eleman boyutu $0.1 \mathrm{~mm}$ olarak belirlenmiştir. Kesme simülasyonlarında 3 boyutlu 10 düğümlü tetrahedron mesh kullanılmış olup [14], kesici takımın uç kısmına doğru daha yoğun olacak şekilde ayarlanmıştır (Şekil 1). 


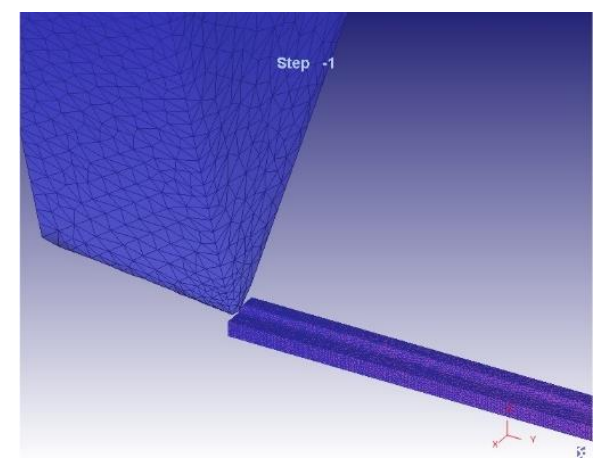

Şekil 1. Kesici takım ve iş parçası a $\breve{g}$ yapısı

Kesme simülasyonları için yaygın olarak kullanılan Johnson-Cook malzeme modeli [12] Eşitlik 1'de verilmiştir [15]. Bu malzeme modeli özellikle metallerin yüksek gerinim deformasyon hızının modellenmesi için uygun olup, genellikle adyabatik geçici dinamik analizlerde kullanılmaktadır. Sertleştirme, akma gerilmesinin $\sigma^{0}$ olarak kabul edildiği izotropik sertleştirmenin belirli bir çeşididir [16].

$$
\sigma^{0}=\left(A+B\left(\varepsilon^{p}\right)^{n}\right)\left(1+C \log \left(\frac{\dot{\varepsilon}^{p}}{\dot{\varepsilon}_{0}}\right)\right)\left(1-\left(\frac{T-T_{r}}{T_{m}-T_{r}}\right)^{m}\right)
$$

Eşitlik 1'de verilen malzeme modeli parametreleri sırasıyla, akma gerilmesi (A), gerinim sertleşmesi (B), gerinim hızı sabiti $(C)$, gerinim sertleşmesi sabiti $(n)$ ve 1 sıl yumuşama $(m)$ sabitidir. Diğer parametreler ise $\varepsilon^{p}, \dot{\varepsilon}^{p}, \dot{\varepsilon}_{0}, T_{r}, T_{m}$ ve $T$ sirasiyla plastik gerinim, plastik gerinim oran1, referans gerinim oran1, oda sıcaklığı, ergime sıcaklığg ve referans sıcaklığıdır. Ayrıca, $\dot{\varepsilon}_{0}$ ve $C$ değerleri referans sıcaklığında ölçülür. X40CrMoV5-1 çeliği için Johnson-Cook malzeme modeli parametreleri Tablo 4'te verilmiştir.

Tablo 4. X40CrMoV5-1 çeliği için malzeme modeli (Johnson-Cook) parametreleri [17]

\begin{tabular}{|l|c|c|c|c|c|c|}
\hline Malzeme & $A$ & $B$ & $n$ & $C$ & $m$ & $T_{m}$ \\
\hline X40CrMoV5-1 & 715 & 329 & 0,28 & 0,03 & 1,5 & 1427 \\
\hline
\end{tabular}

\section{SONUÇLAR VE TARTIŞMA (RESULTS AND DISCUSSION)}

Şekil 2'de verilen etkileşim grafikleri tornalama yönteminde enerji tüketimini birincil olarak etkileyen esas kesme kuvveti $(\mathrm{Fc})$ 'nin kesme parametrelerine göre değişimini göstermektedir. Fc değeri artan kesme derinliği ve ilerleme miktarını bağlı olarak artmaktadır. Fc değerlerinin artışı, kesme derinliği ve ilerleme miktarının artmasıyla artan talaş kesit alanı ve buna bağlı olarak talaş kaldırmak için gerekli olan güç gereksiniminin artmasına atfedilmektedir. Ancak, özellikle kaplamalı CBN takımla elde edilen kesme kuvvetlerindeki artışların düzensiz bir eğilimde olduğu görülmektedir (Şekil 2). Fc değerlerindeki bu düzensiz eğilimin Taguchi $\mathrm{L}_{32}$ deney tasarımı nedeniyle kesme derinliğinin karmaşık dağılımından kaynaklandığı düşünülmektedir. Diğer yandan, kesme hızı açısından her iki kesici takım kalitesi için benzer sonuçlar elde edilmiş olup, kesme hızının artmasıyla birlikte Fc değerlerinde önemli bir azalmanın olmadığı görülmektedir. Bu sonuç, sert tornalama işleminde kesme hızının enerji tüketimi açısından önemli bir etkiye sahip olmadığı kanıtlamaktadır. 


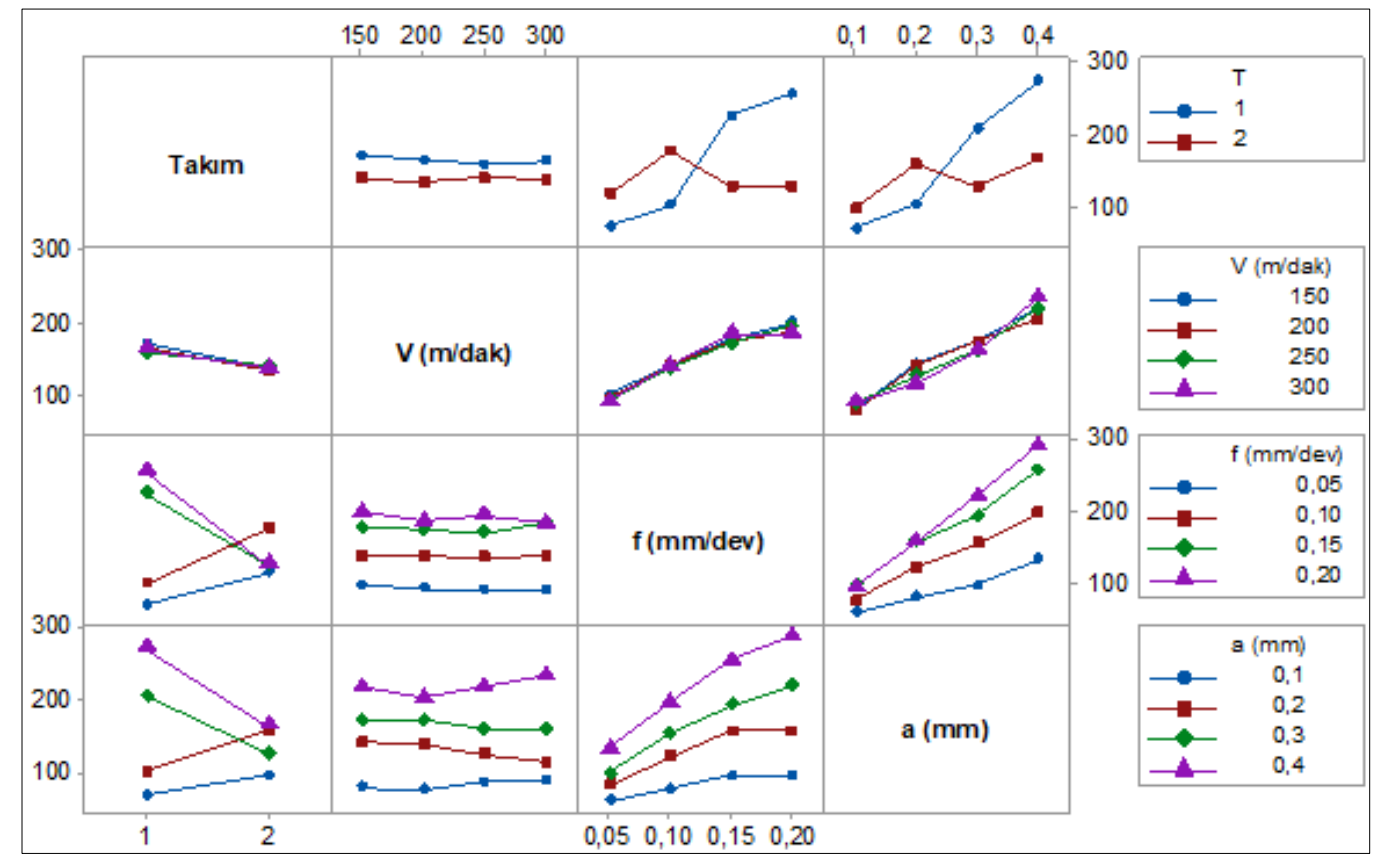

Şekil 2. Fc için etkileşim grafikleri

Deneysel ve nümerik analiz sonucu elde edilen değerler karşılaştıııldığında elde edilen Fc değerlerinin benzer eğilim sergilediği belirlenmiştir. Fc değerlerinin deneysel ve nümerik analiz sonuçlarını içeren kesme parametrelerine göre değişimleri Şekil 3'de verilmiştir. Deneysel ve nümerik analiz sonuçları değerlendirildiğinde, Fc değerinde kaplamasız ve kaplamalı kesici takımlar için sırasıyla ortalama \%94 ve $\% 91$ oranında benzerlik olduğu tespit edilmiştir. Ayrıca, kesme parametreleri açısından yapılan karşılaştırmalarda deneysel ve nümerik analiz sonuçlar arasında maksimum fark \%16 olarak elde edilmiştir. Bu sonucun, kesme simülasyonları için literatürden alınan X40CrMoV5-1 takım çeliği için Johnson-Cook model parametreleri ve kesici takım ve iş parçası ara yüzeyi sürtünme katsayısı nedeniyle olduğu düşünülmektedir. Standart kabul edilerek üretilmiş malzemelerin kimyasal bileşim ve metalografik yapılarının farklı olabileceği durumu literatürde bahsedilmektedir [18-20]. X40CrMoV5-1 takım çeliğinin tornalanmasında deneysel ve nümerik analiz sonuçları arasındaki benzerlik DEFORM 3D'de sonlu elemanlar modelinin uygunluğunu göstermektedir.

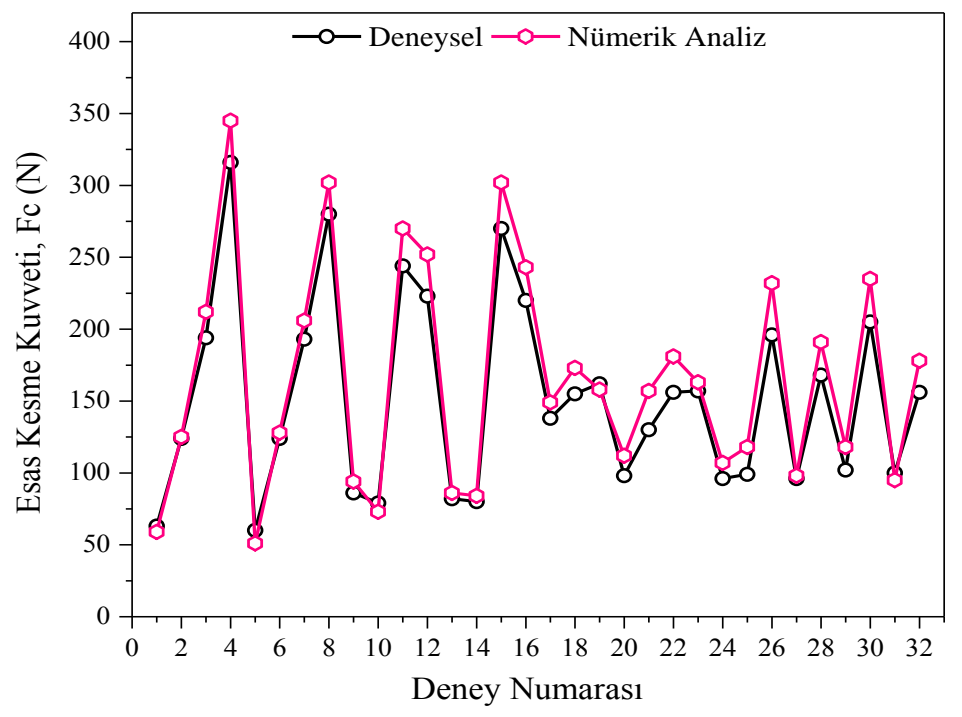

Şekil 3. Deneysel ve nümerik analiz sonuçlarının karşılaştırılması

Kesme parametrelerinin esas kesme kuvveti üzerindeki etki derecelerini tespit etmek amaciyla \%95 güven düzeyinde varyans analizi için uygulanmıştır (Tablo 5). Burada, anlamlılık düzeyini gösteren $\mathrm{P}$ değeri, 
kareler ortalaması (MS), kareler toplamı (SS), serbestlik derecesi (DF), F değerleri ve yüzde katkı oranları (PCR) değerlerinin her bir parametre için elde edilen çıktılar üzerindeki sonuçları görülmektedir. Ayrıca, parametrelerin esas kesme kuvveti üzerindeki etkileri grafiksel olarak Şekil 3'te görülmektedir. Uygulanan kesme şartlarında, Fc değeri için en etkili değişkenin \%58.88 PCR ile kesme derinliği olduğu belirlenmiş olup, Şekil 4 ana etki grafiği bu sonucu desteklemektedir. Fc üzerinde etkili olan diğer parametreler sırasıla \%33.61 ve \%4.08 PCR ile ilerleme miktarı (f) ve kesici takım (T)'dır.

Tablo 5. Fc için ANOVA sonuçları

\begin{tabular}{|l|c|c|c|c|c|c|}
\hline Parametre & DF & SS & MS & F & P & PCR (\%) \\
\hline T & 1 & 5505 & 5504,6 & 25,79 & 0,000 & 4,08 \\
\hline V & 3 & 154 & 51,3 & 0,24 & 0,867 & 0,11 \\
\hline f & 3 & 45330 & 15110,1 & 70,80 & 0,000 & 33,61 \\
\hline a & 3 & 79413 & 26471,1 & 124,04 & 0,000 & 58,88 \\
\hline Hata & 21 & 4482 & 213,4 & & & 3,32 \\
\hline Toplam & 31 & 134884 & & & & 100 \\
\hline
\end{tabular}

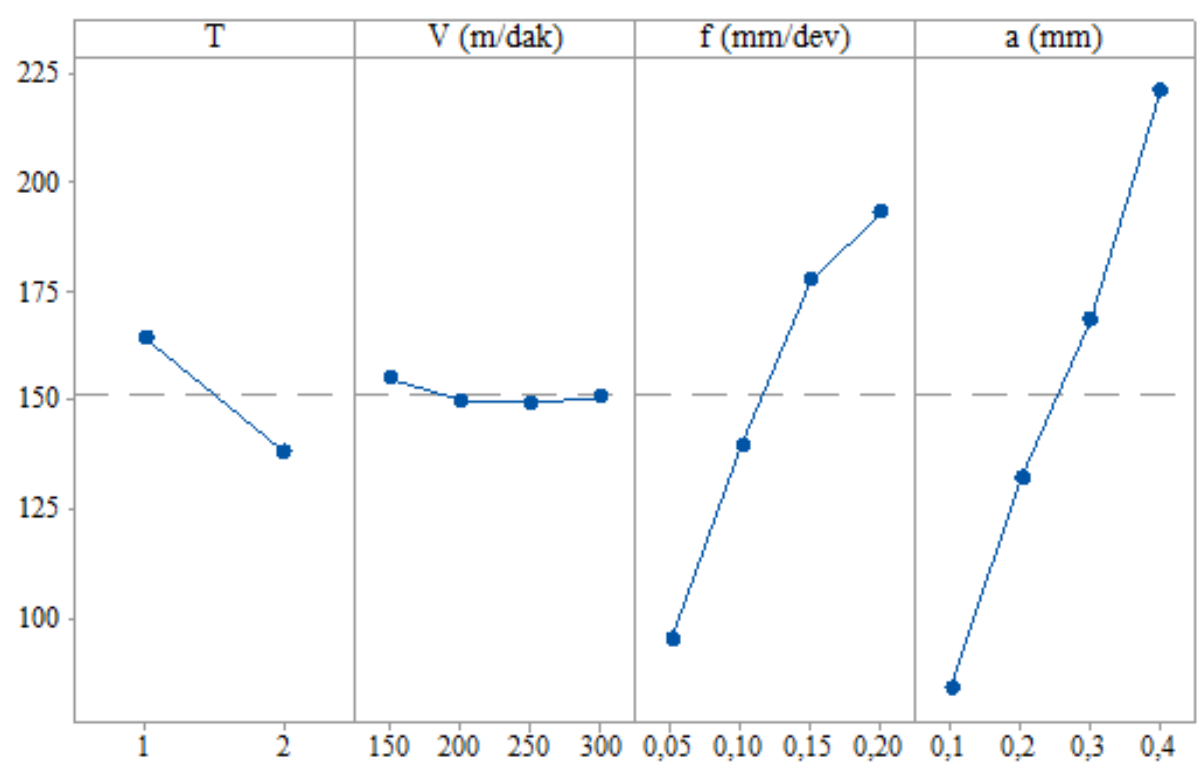

Şekil 4. Fc için ana etki grafiği

\section{SONUÇLAR (CONCLUSIONS)}

Bu çalışmada, sertleştirilmiş X40CrMoV5-1 takım çeliğinin kaplamalı ve kaplamasız CBN kesici takımlar kullanılarak sert tornalanmasında esas kesme kuvveti (Fc)'nin değişimi araştırılmıştır. Ayrıca, deneysel olarak elde edilen sonuçlar ile sonlu elemanlar yöntemine dayalı olarak yapılan kesme simülasyonlarında elde edilen sonuçlar karşı1laştırılmıştır.

- Deneysel ve nümerik analiz sonuçlarına göre, artan kesme derinliği ve ilerleme miktarına bağlı olarak Fc değeri artmaktadır.

- ANOVA sonuçlarına göre en etkin değişken kesme derinliği ve ilerleme miktarı olup etki oranları sirasiyla \%58.88 ve \%33.61 PCR olarak tespit edilmiştir.

- Belirlenen kesme şartlarında optimum kesme parametreleri, kaplamasız takım, 200 m/dak kesme hızı, $0.05 \mathrm{~mm} / \mathrm{dev}$ ilerleme miktarı ve $0.1 \mathrm{~mm}$ kesme derinliği olarak belirlenmiştir.

- Nümerik analiz sonuçları deneysel sonuçlar ile karşılaştırıldığında, Fc değerlerinin kaplamasız takımlar için \%94, kaplamalı takımlarda ise \%91 oranında benzer olduğu tespit edilmiştir. Bu sonuçlar kullanılan sonlu elemanlar yönteminin uygunluğunu göstermektedir. 


\section{KAYNAKLAR (REFERENCES)}

[1] H. K. Tonshoff, C. Arend, R. B. Amor, Cutting of hardened steel, CIRP Annals- Manufacturing Technologies. 49:2 (2000) 547-566.

[2] F. Hashimoto, Y. B. Guo, A. W. Warren, Surface integrity difference between hard turned and ground surfaces and its impact on fatigue life. CIRP Annals- Manufacturing Technologies, 55:1 (2006) 81-84.

[3] Y. Huang, Y. K. Chou, S. Y. Liang, CBN tool wear in hard turning: a survey on research progresses. International Journal of Advanced Manufacturing Technology, 35 (2007) 443-453.

[4] I. Meddour, M. A. Yallese, R. Khattabi, M. Elbah, L. Boulanouar, Investigation and modeling of cutting forces and surface roughness when hard turning of AISI 52100 steel with mixed ceramic tool: cutting conditions optimization. International Journal of Advanced Manufacturing Technology, 77 (2015) $1387-1399$.

[5] H. Aouici, M. A. Yallese, K. Chaoui, T. Mabrouki, J. F. Rigal, Analysis of surface roughness and cutting force components in hard turning with $\mathrm{CBN}$ tool: prediction model and cutting conditions optimization. Measurement, 45 (2012) 344-353.

[6] K. Bouachaa, M. A. Yallese, T. Mabrouki, J. F. Rigal, Statistical analysis of surface roughness and cutting forces using response surface methodology in hard turning of AISI 52100 bearing steel with CBN tool. International Journal of Refractory Metals and Hard Materials, 28:3 (2010) 349-361.

[7] S. H. Oh, A Study on cutting force characteristics in hard turning. International Journal of Control and Automation, 7:3 (2014) 137-146.

[8] V. Vijayaraghavan, A. Garg, L. Gao, R. Vijayaraghavan, G. Lu, A finite element based data analytics approach for modeling turning process of Inconel 718 alloys. Journal of Cleaner Production, doi:10.1016/j.jclepro.2016.04.010.

[9] N. Yaşar, M. Sekmen, M. E. Korkmaz, M. Günay, AISI P20 çeliğinin işlenmesinde kesme kuvvetinin deneysel ve nümerik analizi. GU J Sci Part:C, 4:1 (2016) 625-631.

[10] K. Gök, Development of three-dimensional finite element model to calculate the turning processing parameters in turning operations. Measurement, 75 (2015) 57-68.

[11] H. Yurtkuran, DIN 1.2344 Çeliğinin tornalanmasinda oluşan kesme kuvvetleri ve yüzey pürüzlülügünün modellenmesi. Karabük Üniversitesi Fen Bilimleri, Yüksek Lisans Tezi, Mayıs, 2013.

[12] H. Yan, J. Hua, R. Shivpuri, Flow stress of AISI H13 die steel in hard machining. Materials and Design, 28 (2007) 272-277.

[13] L. Tang, J. Huang, L. Xie, Finite element modeling and simulation in dry hard orthogonal cutting AISI D2 tool steel with CBN cutting tool. International Journal of Advanced Manufacturing Technology, 53 (2011) 1167-1181.

[14] M. E. Korkmaz, M. Günay, Finite Element Modelling of Cutting Forces and Power Consumption in Turning of AISI 420 Martensitic Stainless Steel. Arabian Journal for Science and Engineering, (2018), DOI: $10.1007 / \mathrm{s} 13369-018-3204-4$

[15] G. J. Johnson, W. H. Cook, A constitutive model and data for metals subjected to large strains, high strain rates and high temperatures. In: Proceedings of the Seventh International Symposium on Ballistics, The Hague, (1983) 541-547. 
[16] A. Dorogoy, D. Rittel, Determination of the Johnson-Cook Material Parameters Using the SCS Specimen. Experimental Mechanics 49 (2009) 881-885.

[17] Y. Karpat, T. Özel, 3-D FEA of Hard Turning: Investigation of PcBN cutting tool micro- geometry effects. Trans NAMRI/SME, 35 (2007) 9-16.

[18] H. Bil, S. E. Kilıç, A. E. Tekkaya, A comparison of orthogonal cutting data from experiments with three different finite element models. International Journal of Machine Tools and Manufacture, 44:9 (2004) 933-944.

[19] T. Özel, E. Zeren, Finite element method simulation of machining of AISI 1045 steel with a round edge cutting tool. Proceedings of 8th CIRP International Workshop on Modeling of Machining Operations, Germany, (2005) 533-542.

[20] T. Özel, The influence of friction models on finite element simulations of machining. International Journal of Machine Tools and Manufacture, 46 (2006) 518. 